化し，パラー>オルトー>メタ置換体の順に反応性は減ずる。また 反応の平衡もこの順序にしたがう。しかし，この差は極く小さい ので, 実際の反応ではその影響は余り顕著に現われないものと思 われる。

次に反応（7）の場合も反応（6）のときと同様の傾向にある ことがわかる。そして，この両反応の平衡定数 $\log K_{\mathrm{p}}$ の差をと れば高温になるほど, その值が小さくなり, 高温では反応（6） が起り易く，温度の低い方では反応（7）が有利なことがわかる。 本実験の条件は $800^{\circ} \mathrm{C}\left(1073^{\circ} \mathrm{K}\right)$ 以上であり, 添加水蒸気の量も 反応（6）に相応するモル比を採用したため，反応（7）の起る 率は極く僅かなものでむると思われる。

\section{5 総括}

以上の結果を総括して結論を述べる。

（1）中性担体触媒と塩基性担体触媒で水蒸気反応に著しい差 異が認められ，接触効果は中性担体の方がすぐれていた。生成ガ
スの組成は中性担体では，水素と一酸化炭素の和が 80 90\% に 達し, 反応温度による差がすくない。塩基性担体では炭化水素の 生成が多く，熱分解に近い結果を示し，また接触温度の影響も大 きい。

（2）同系列の炭化水素の反応の容易さは，中性担体触媒を用 いると，炭素数の少ない炭化水素の方が反応し易く，塩基性担体 触媒では炭素数の多いものが反応し易い。芳香族炭化水素の場合 は両触媒とも同じ傾向を示し，側鎖の大きい方が反応を起し易 W。

（3），中性担体触媒は著しく脱水素反応を促進し, 塩基性担体 触媒では脱メチルと脱水素の両反応が大体平行して起っている。

（4）炭化水素の標準生成自由エネルギーの温度式より水蒸気 反応の標準自由エネルギー，平衡定数を算出した。それらの結果 と実験の結果はかなりの一致をみた。

本研究の一部は文部省の試験研究費によったものであり，本実 験に協力をいただいた渡辺恵嗣君に厚く感謝いたし米す。

\title{
脂肪族アルコールのペーパークロマトグラフィー†
}

（昭 和 35 年 6 月 2 日 受 理）

\author{
丸田 銓二朗・鈴木 義 仁・岩間 文 男*
}

\begin{abstract}
脂肪族アルコールと二重結合のあるマレイン酸およびクロトン酸とのエステルを合成し，さらにェステルの酢酸第二水 銀付加物をつくった。これらの付加物を展開試料とする逆相ペーパークロマトグラフィーについて研究した。脂肪族アル コール $\left(\mathrm{C}_{2} \sim \mathrm{C}_{18}\right)$ を用いて合成した試料のハン（斑）点は明確に分離するので定性分析法として適当である。

試料の量とハン点の面積ならびに吸光度との関係を検討し，ハン点の面積と使用した試料の量との間には比例的関係の あることを明らかにした。
\end{abstract}

\section{1 緒言}

アルコール類のペーパークロマトグラフィーを行なら場合に は, 試料のハン点の検出が容易に出来るよ5にするとともに低級 アルコールの揮発性を減少させるため 3,5-ジニトロベンジェー

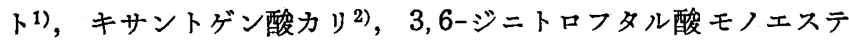
ル8), フタル酸モノェステル4)等のアルコール誘導体を合成して 展開試料とすることが多い。著者らはアルコールをとのまま展開 試料とするペーパークロマトグラフィーについて報告した5)。

本報告に持いては，脂肪族アルコール $\left(\mathrm{C}_{2} \sim \mathrm{C}_{18}\right)$ とマレイン酸 およびクロトン酸とのエステルをつくり，エステルの酢酸第二水 銀付加物を合成した6)。この付加物を展開試料とするペーパーク ロマトグラフィーについて研究した結果を報告する。

$†$ 本報告を「アルコールに関する研究（第 3 報)」とする.

* 山梨大学化学教室 : 甲府市元柳町.

1) D. F. Meigh, Nature 169, 706 (1952).

2) T. Kariyone, Y. Hashimoto, Nature 168, 511 (1951); 薬誌 73, 1093 (1953).

3) 百瀬, 山田, 薬誌 71, 980 (1951).

4) 七字, 林, 酳醭研 14, 15 (1957).

5) 丸田, 岩間, 日化 80, 1131 (1959).

6) A. W. Ralston, C. W. Christensen, G. Josh, Oil \& Soap 14, 5(1937); Y. Inouye, M. Noda, O. Hirayama, J. Am. Chemists' Soc. 32, 132 (1955).

\section{2 実験および結果の考察}

\section{$2 \cdot 1$ 試 料}

エタノール $n$-ブタノール $n$-ヘキサノール $n$-オクタノ一 ル, $n$-デカノール, $n$-ドデカノール, $n$-テトラデカノール $n$ ヘキサデカノール, n-オクタデカノール等のアルコールは市販品 を再蒸留法括よび再結晶法で精製した。これらのヒドロキシル価 から計算すると純度はいずれも $99.5 \%$ 以上であった。無水マレ イン酸,クロトン酸, 酢酸第二水銀等は市販特級品を用いた。酢 酸第二水銀をロダン法で分析し，試薬の純度は $99.89 \%$ であるこ とを確かめた。酢酸（A)，メタノール(M)，エタノール(E), テトラリン(T), 石油炭化水素 bp $140 \sim 160^{\circ} \mathrm{C}(\mathrm{P})$, デカリン(D) 等は市販品を再蒸留して使用した。

\section{$2 \cdot 2$ 定 性 分 析}

$2 \cdot 2 \cdot 1$ マレイン酸エステルを用いる方法

a）展開試料の調製：試料アルコール $20 \mathrm{mg}$ と 3 倍当量の無 水マレイン酸とを還流冷却器付フラスコに入れ湯浴上で 1 洔間加 熱し，アルュールのマレイン酸モノェステルをつくった。冷却後 四塩化炭素と水とを $10 \mathrm{cc}$ ずつ加えてかきまぜ水層を除き，水洗 をくり返して未反応のマレイン酸を除いた。四塩化炭素溶液層に 脱水ボウ硝を加えて乾燥, 口過し, 四塩化炭素を蒸留除去してア ルコールのマレイン酸モノエステルを得た。このエステルを $2 \mathrm{cc}$ 
のメタノールに溶かし, 1.5 倍当量の酢酸第二水銀を加えて 80 ${ }^{\circ} \mathrm{C}$ K 30 分加熱してアルコールのマレイン酸モノェステルの酢 酸第二水銀付加物をつくった。ベンゼン $5 \mathrm{cc}$ と水 $10 \mathrm{cc}$ とを加 えてよくかきまぜ，水を除き水洗をくり返した。上層のベンゼン 溶液を展開試料とした。

b) ペーパークロマトグラフィー：東洋濾紙 No. 50 を $40 \times 2$ $\mathrm{cm}$ に切り，テトラリンを約 $0.15 \mathrm{~g} / 100 \mathrm{~cm}^{2}$ の割合に噴霧し， 一端より $5 \mathrm{~cm}$ の所に試料約 $10 \gamma$ を付着させ, $30^{\circ} \mathrm{C}$ の恒温器中 で上䄯法で展開した。展開溶媒の上年先端が原点より約 $20 \mathrm{~cm}$ 上界したとき口紙を取り出し, 風乾した後 $0.2 \%$ のジフェニルカ ルバッ゙ンのアルコール溶液(発色剤)を噴霧するとハン点は紫色に 発色する。さらに $0.01 \%$ の硝酸を含むアルコール溶液を噴霧す るとハン点の色は青色にかわりハン点が明確になる事がある。

脂肪族アルコール $\left(\mathrm{C}_{2} \sim \mathrm{C}_{18}\right)$ のマレイン酸モノェステルの㼍酸 第二水銀付加物の $R_{f}$ 值を表 1 に示した。

表 1 マレイン酸モノェステルの酢酸第二水銀付加物の $R_{f}$ 值

\begin{tabular}{|c|c|c|c|}
\hline 分 & I & II & III \\
\hline 展 開 溶 & $M^{*}: A: T$ & $\mathrm{M}: \mathrm{A}: \mathrm{T}$ & $M: A: T$ \\
\hline 混合 & $10: 1: 1$ & $10: 1: 2$ & $10: 1: 3$ \\
\hline 武料** 固定溶媒 & $T$ & $T$ & $\mathbf{T}$ \\
\hline$x \not ノ-ル$ & 0.85 & 0.68 & 0.67 \\
\hline n-ブタノール & 0.85 & 0.66 & 0.63 \\
\hline nーヘキサノール & 0.84 & 0.64 & 0.55 \\
\hline n-オクタノール & 0.76 & 0.56 & 0.48 \\
\hline$n$-デカノール & 0.64 & 0.48 & 0.45 \\
\hline nードデカノール & 0.57 & 0.44 & 0.41 \\
\hline n-テトラデカノール & 0.53 & 0.42 & 0.39 \\
\hline nーヘキサデカノール & $0.47^{\circ}$ & 0.39 & 0.35 \\
\hline n-オクダデカノール & 0.44 & 0.35 & 0.30 \\
\hline \multicolumn{4}{|c|}{ * 表1以下の M は 90\% メタノールをあらわす } \\
\hline \multicolumn{4}{|c|}{ ** 展開試料を合成するのに用いたアルコールを記した } \\
\hline \multicolumn{4}{|c|}{ *** 本報告では溶剤の混合比は容量比であらわした } \\
\hline
\end{tabular}

区分III場合に最もよい結果が得られた。しかし区分 I，II，III のいずれの場合においても全部の試料を混合した場合には各ハン 点の中心は識別することが出来るが，各ハン点が完全には分離し なかった。炭素数の差が 6 以上あるアルコールを用いて合成した 試料を混合した場合にはハン点が完全に分離した。マレイン酸エ ステルを用いると，ハン点が大きくなり易く，また尾を引くこと が多かった。

\section{$2 \cdot 2 \cdot 2$ クロトン酸エステルを用いる方法}

a） 展開試料の調製：nーヘキサノールより分子量の大きいアル コールを用いる場合には次のようにした。アルコール $20 \mathrm{mg}$ フラスコに採り，クロトン酸を当量より $20 \%$ 過剰に加え, さら にアルコールと酸との合計量に対して $0.2 \%$ の $p$-トルエンスル ホン酸を加壳た。

フラスコに還流冷却器を付けて油浴上で $130^{\circ} \mathrm{C}$ に 30 分加熱し た。冷却後 $\mathrm{N} / 10$ 水酸化ナトリウムで中和し, エーテルに溶かし た後水洗した。エーテルを蒸留除去して得たエステルをメタノー ル $2 \mathrm{cc}$ に溶かし，2·2・1 に記したマレイン酸エステルの場合と 同様に処理して酢酸第二水銀付加物を合成して展開試料とした。 クロトン酸エチルを合成する場合には湯浴上で 3 時間加熱し, ク ロトン酸ブチルを合成する場合には $117^{\circ} \mathrm{C} に 90$ 分加熱した。そ の他の操作はへキサノールを用いた場合と同様に処理して展開試 料をつくった。

b）ペーパークロマトグラフィー：展開温度を $20^{\circ} \mathrm{C}$ とた以 外は $2 \cdot 2 \cdot 1$ b) に記したと同様に操作した。固定相として用いる
液の噴霧量は実験結果に大きな影響を与えるので特に注意する必 要がある。固定相とする溶媒は約 $0.15 \mathrm{~g} / 102 \mathrm{~cm}^{2}$ が適当であっ た。

実験結果を表 2 に示した。

表 2 クロトン酸エステルの酷酸第二水銀付加物の $R_{f}$ 值

\begin{tabular}{|c|c|c|c|c|c|}
\hline 分 & I & II & III & IV & $\boldsymbol{\nabla}$ \\
\hline 展 開 溶 媒 & $\mathbf{M}: \mathbf{A}: \mathbf{T}$ & $E: A: D$ & $\mathbf{M}: \mathbf{T}$ & $\mathbf{M}: \mathbf{D}$ & $\mathbf{M}: \mathbf{P}$ \\
\hline 混 合 此 & $10: 1: 1$ & $30: 5: 3$ & $20: 3$ & $8: 1$ & $20: 3$ \\
\hline 試料* & $T$ & D & $\mathbf{T}$ & D & $\mathbf{P}$ \\
\hline エ,$-ル$ & 0.73 & 0.98 & 0.65 & 0.68 & - \\
\hline ブタ, - ル & 0.68 & 0.98 & 0.57 & 0.68 & - \\
\hline ヘキサノール & 0.64 & 0.97 & 0.49 & 0.67 & 0.70 \\
\hline オクタノール & $0: 47$ & 0.95 & 0.40 & 0.68 & 0.60 \\
\hline デカノール & 0.41 & 0.82 & 0.34 & 0.53 & 0.53 \\
\hline ドデカノール & 0.34 & 0.74 & 0.27 & 0.50 & 0.46 \\
\hline テトラデカノール & 0.27 & 0.68 & 0.21 & 0.28 & 0.38 \\
\hline ヘキサデカノール & 0.18 & 0.57 & 0.16 & 0.19 & 0.29 \\
\hline オクタデカノール & 0.10 & 0.48 & 0.10 & 0.16 & 0.19 \\
\hline
\end{tabular}

* 展開武料を合成するのに用いたアルコールを記した

表 2 の区分 I およびIIIが適当であった。特に区分 I Kおいては ハン点が小さくまとまり，相互の分離状態が良好であった。

c) ハン点の吸光度：6種類の試料がおのおの $0.15 \mathrm{mg}$ ずつ 含まれている試料溶液を原点に付着させ, 表 2 区分 I の条件で展 開した後発色剂を噴霧した。島津製ペーパークロマトグラフ用付 ・属装置に口紙を挾み，口紙の透過率が 100\%になるよ5に調節し た。次に試料を展開した口紙を挾み $2 \mathrm{~mm}$ ずつ移動させ，石英 分光光度計で $580 \mathrm{~m} \mu$ に打る吸光度を測定した。ハン点と吸光 度との関係は図 1 に示した。

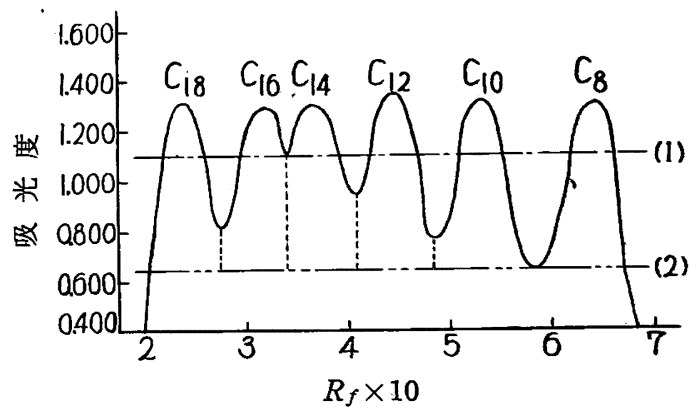

図 1 八 点の吸光度

（1）（2）はそれぞれ基染楾 1 および2とする

曲線の極大に付記した $\mathrm{C}_{8} \sim \mathrm{C}_{18}$ は相当するアルコールから合成 した試料のハン点を示す。

図1から明らかなよ5にハン点は明確に分離する。図 1 におい て, 吸光度曲線の谷の一番浅い点と深い点とを通り横軸に平行な 線をひきそれぞれ基準線 1 および 2 とした。基準線と吸光度曲線 との間の面積を $\mathrm{cm}^{2}$ 単位で求めた。その結果を表 3 に示した。

表 3 吸光度曲線と基準線との間の面積

\begin{tabular}{ccccccc} 
ハン点 & $\mathrm{C}_{8}$ & $\mathrm{C}_{10}$ & $\mathrm{C}_{12}$ & $\mathrm{C}_{14}$ & $\mathrm{C}_{10}$ & $\mathrm{C}_{18}$ \\
\hline 基啭 & & & & & & \\
\hline (1) & 0.80 & 0.85 & 0.85 & 0.83 & 0.80 & 0.83 \\
(2) & 3.40 & 3.35 & 3.43 & 3.43 & 3.35 & 3.40
\end{tabular}

同一量 $(0.15 \mathrm{mg})$ の試料を用いた場合には各ハン点の吸光度 曲線と基準線との間の面積は表 3 に示したようにほぼ一定にな る。

\section{$2 \cdot 3$ 定 量 分 析}

アルコールをクロトン酸エステルとし，その酶酸第二水銀付加 物を用いるペーパークロマトグラフィーでアルコールを定量する 
ため，エステル化反応と酢酸第二水銀付加反応の収率拈よびハン 点の面積に拉よぼす諸条件について唡討した。

2.3・1 エステルの収率 p-トルェンスルホン酸, ベンゼンス ルホン酸, ピリジン, 硫酸等を触媒として種々の条件で実験し, 生成物の収量, 水酸基価, ケン化価, エステル価, 酸価等を測定 しエステルの収率を求めた。その結果アルコール $1 \mathrm{~mol}$ に対し クロトン酸 $2 \mathrm{~mol}$ の割合に混合し、アルコールと酸の合計量に 対し $0.2 \%$ のトルエンスルホン酸を加党，nーヘキサノールより分 子量が大きいアルコールを用いるときは $130^{\circ} \mathrm{C}$ K 30 分, n-ブ タノールを用いるときは $117^{\circ} \mathrm{C} に 90$ 分加熱するのが適当である ことを知った。この反応条件では各アルコール $\left(\mathrm{C}_{4} \sim \mathrm{C}_{18}\right)$ とも $97.5 \pm 0.4 \%$ の収率でクロトン酸エステルとなった。

2.3.2 酷酸第二水銀付加物の収率 $n$-ドデカノールのクロト ン酸エステルを2.3.1 亿記した方法で合成し， $2 \cdot 2 \cdot 1$ 亿記した方 法て酢酸第二水銀付加物を得た。この付加物の水銀含有率を口ダ ン法で定量した。水銀含有率は $34.4 \%$ であった。エステルの収 率を $97.5 \%$ とし，付加物の構造は Ralstone') らの式であらわ されるとして水銀の含有率を計算すると $34.6 \%$ となる。エステ ルへの酢酸第二水銀の付加は定量的に行なわれることがわかっ た。

2.3.3 定量のためのペーパークロマトグラフィー 表 2 , 区 分Iの方法に準じて行ないン点の面積をプラニメーターで測定 した。定量のため次の事項に注意して行なった。展開試料を 10 ccのメスフラスコに科取し、イソプロピルエーテルを加光，0.3\% 程度の溶液とした。メスピペットで試料の直径が $5 \mathrm{~mm}$ 以下に なるように付着させた。展開終了後口紙をガラス円筒より取り出 し, 室温で 30 60 分風乾して後, 発色剂を噴霧した。発色剂は 調製後 5 日以内のすのを使用した。発色後 24 時間以内にハン点 の面積を測定した。

2.3.4 検量線 n-オクタデカノールから合成した展開試料 $0.03 \sim 0.30 \mathrm{mg}$ を紙上の原点に付着させ, 2.3 .3 の方法でペー パークロマトグラフィーを行なった。使用した展開試料の量と八 ン点の面積との関保を図 2 に示した。
测定値は図 2 と示した二 破線間汹めた。二破線の 中央を通る直線を実線で示 した。この実線を $n$-オク タデカノールから合成した 展開試料の検量線とした。 nーヘキサノール, $n$ ーオク タノール, $n$-デカノール, nードデカノール, $n$-テトラ デカノール, $n$ ーヘキサデカ ノール等から合成した展開 試料について\& $n$-オクタ デカノールから合成した展 開試料の場合と同様にそれ ぞれの検量線をつくること 成出来た。

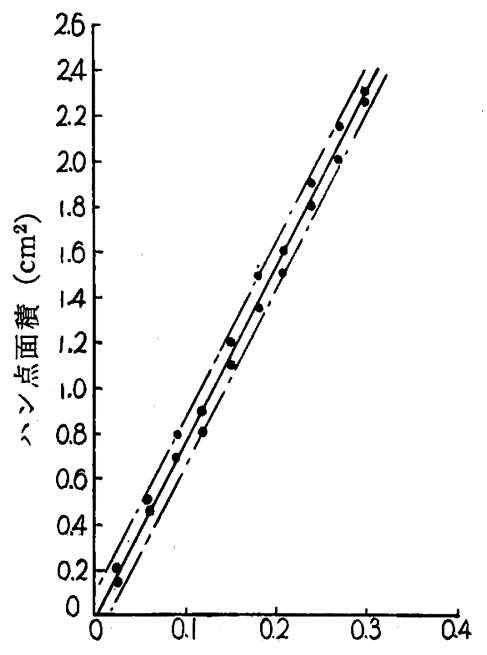

試料 (mg)

図 2 試料の量とハン点面積 nーオクタデカノールを用いる展開試料を再び合成し，検量線を 求めたのと同一方法でペーパークロマトグラフィーを行なった。 ハン点の面積を測り，その測定値と検量線とから展開試料の量を 求めた。実験結果を表 4 に示した。

表 4 実験法の精度と再現性

\begin{tabular}{|c|c|c|c|}
\hline 実験番号 & $\begin{array}{c}\text { 供 試 量 } \\
\text { (mg) }\end{array}$ & $\begin{array}{c}\text { 测 定 储* } \\
(\mathbf{m g})\end{array}$ & （湘定値/供武量） $\times 100$ \\
\hline 1 & 0.15 & 0.144 & 96 \\
\hline 2 & 0.15 & 0.143 & 95 \\
\hline 3 & 0.15 & 0.153 & 105 \\
\hline 4 & 0.30 & 0.302 & 101 \\
\hline 5 & 0.30 & 0.292 & 97 \\
\hline 6 & 0.30 & 0.312 & 104 \\
\hline
\end{tabular}

表 4 で実験番号 1 と 4 は同時に，2 と 5 は翌日，3 と6 は翌翌 日に行なった。

表 4 から明らかなよ こに，この実験法による测定值の誤差は $\pm 5 \%$ 以内である。

（昭和 35 年 4 月, 日化第 13 年会檴演)

\section{正 $\underset{\text { (著者の申出による) }}{\text { 誤 }}$ 表}

誤

河野, 尾頃, 稲葉, 工化 61,1462 (1958) 右表 2 上

山田, 工化 62, 510 (1959) 右本文下から 4 行目 511 (1959) 左図 3 下

菊池, 工化 62, 1868 (1959) 左表 7 の 3 行上 中, 野田, 工化 63, 1326 (1960) 左表 3 中

$\begin{array}{lll}\text { 同 } & \text { 上 } & \text { 左表 } 4 \text { 中 } \\ \text { 同 } & \text { 上 } & \text { 右 } 20 \text { 行 } \\ \text { 同 } & \text { 上 } & \text { 右写真 } 1 \text { の説明 } \\ & 1327(1960) & \text { 左本文 } 11 \text { 行 }\end{array}$

$\Delta F=41,775+9.08 T \log T+4.91 T$ $-1.59 \times 10^{-3} T^{2}+0.36 \times 10^{-7} T^{3}$

$\Delta S=\Delta v / r$

$S=\sum \Delta v / \bar{r}$

$\cdots \cdots$ 测定した結果 $266 \mu$ の…

PK 10-101 $1335 \quad \ldots \ldots$

PK 20-106 $1273 \quad \ldots \ldots$

…a (PK 02-11) は.....

$\mathrm{a}(\mathrm{PK} \mathrm{02-11)} \times 18$ 十字ニコル

・フッ化カリウムの晶化割として .
正

$\Delta F=3,225+9.08 T \log T-37.09 T$ $-1.59 \times 10^{-3} T^{2}+0.36 \times 10^{-7} T^{3}$ $\Delta S=2 \Delta v / r$ $S=\sum 2 \Delta v / \bar{r}$ $\cdots \cdots$ 測定した結果 $266 \mathrm{~m} \mu$ の…

PK 10-111 $1335 \quad \ldots \ldots$.

PK 20-106 $1274 \quad \ldots \ldots$ …a(PK 02-111) は..... $\mathrm{a}(\mathrm{PK} \mathrm{02-111)} \times 18$ 十字ニコル ・フッ化カリウムの晶化剂として・.

鳥飼, 故多和田, 工化 63,1698（1960）左図4縦軸の説明純 度（\%) 同

上. 英文題名

..... Non-caking Coals

収, 率 $(\%)$

........ Non-caking Coals in the

Formation of Calcium Carbide 